Report

\title{
Evaluation of novel epidermal growth factor receptor tyrosine kinase inhibitors
}

\author{
James M. Rae and Marc E. Lippman* \\ Department of Oncology, Georgetown University Medical Center, Washington, DC; *Present Address: Division of \\ Hematology and Oncology, Department of Internal Medicine, University of Michigan Medical Center, Ann Arbor, \\ MI, USA
}

Key words: epidermal growth factor, epidermal growth factor receptor, neoplastic growth, tyrosine kinase inhibitor

\section{Summary}

The epidermal growth factor system is a well characterized growth factor receptor pathway, the deregulation of which has been be associated with neoplastic growth. Overexpression or amplification of the epidermal growth factor receptor (EGFR) or one of its ligands has been linked with the malignant transformation of cells and is correlated with poor prognosis in patients. PD 153035, a quinazoline, has been shown to inhibit the tyrosine kinase activity of EGFR by blocking ATP binding (Fry et al., Science 265: 1093-1095, 1994). We set out to determine whether the growth inhibition caused by this agent and five related compounds is a direct result of the blocking of EGFR signaling. The effects on cell proliferation produced by these agents were tested on several tumor cell lines and EC50 values obtained. The EGF responsive cell lines A-431 and MDA-MB-468 exhibit EC50 values of 3 and $6.7 \mu \mathrm{M}$, respectively, for PD 153035 which was found to be the most potent. The agents were then tested for their ability to block the paradoxical high dose EGF induced inhibition of A-431 and MDA-MB-468 cell growth as well as EGF induced phosphorylation in A-431 cells. These compounds are able to completely block the effects of exogenously added EGF at $0.5 \mu \mathrm{M}$ or less. However, higher doses (EC50's $\geq 2 \mu \mathrm{M}$ ) were needed to block the growth of human tumor cell lines potentially implicating a second site of action for these compounds.

\section{Introduction}

The epidermal growth factor receptor (EGFR) is a $170 \mathrm{kDa}$ transmembrane protein which exhibits intrinsic tyrosine kinase activity following binding to one of its cognate ligands. Activation of EGFR leads to many cellular responses including mitogenesis and cellular proliferation [1]. Overexpression and/or amplification of EGFR has been found in many human tumors including, gastric, esophageal, breast, prostate, glioblastoma and lung, and has been associated with poor prognosis [2-6]. Co-expression of EGFR and one its ligands in tumor cells can enable growth to occur in an autocrine or paracrine fashion [7]. These characteristics make EFGR an attractive target for anti-cancer therapies.
Therapeutic approaches against this target have included immunotoxins, antibodies and small molecule inhibitors. The recombinant immunotoxin DAB389EGF which consist of a truncated diphtheria toxin fused to EGF has shown promise in preclinical studies [1,8]. Others have fused EGFR ligands with RNase [9] or pseudomonas exotoxin [10]. Another approach is to block the signal transduction pathway. This has been attempted with monoclonal antibodies directed to the extracellular domain of EGFR to prevent the binding of ligands to the receptor. These monoclonals have been shown to block the growth of human tumor cells in vitro and in vivo and promising results from clinical trails have been reported [11-14]. These strategies whilst hopeful are not without problems. Large molecules directed to EGFR such as the 
<smiles>COc1cc2ncnc(Nc3cccc(Br)c3)c2cc1S(=O)(=O)C(C)(C)C</smiles><smiles>Nc1ccc2sc3c(Nc4cccc(Br)c4)ncnc3c2c1</smiles><smiles></smiles><smiles>[CH]N([18OH])c1cc2c(Nc3cccc(Br)c3)ncnc2cn1</smiles><smiles>Cn1cnc2cc3c(Nc4cccc(Br)c4)ncnc3cc21</smiles><smiles>O=C(c1ccccc1)c1cc2nc[nH]c2cc1Nc1cccc(Br)c1</smiles>

Figure 1. Chemical structures of the EGFR tyrosine kinase inhibitors tested.

immunotoxins and blocking antibodies are costly to produce, are susceptible to proteolytic degradation, can elicit an immune response and show poor penetrance into solid tumors $[4,15]$. As a result many groups have been developing small molecule compounds that block the EGFR signal transduction pathway $[14,16]$. These agents can be made more easily and may show increased penetration into solid tumors. Such compounds can be designed to compete for ligand binding, a critical step in EGFR activation, or compete with EGFR-ATP binding, another critical step in EGFR kinase activation. Compounds which block the tyrosine kinase activity of the EGFR by binding the intracellular portion of the receptor may have an advantage over targeting the extracellular region especially in cases where truncation of the extracellular domain of EGFR has led to ligand independent tyrosine kinase activity [17] or where high levels of the shed extracellular domain are present in the serum .

PD 153035 blocks the phosphorylation of tyrosine residues by competing for the ATP binding site [18]. 
Table 1. EC50 values $(\mu \mathrm{M})$ for compounds screened on human tumor cell lines. Cell number quantitated using crystal violet staining assay as described in Materials and methods then plotted as percentage control. EC50 values were determined from resulting dose response curves

\begin{tabular}{lcccccc}
\hline Cell line & PD 153035 & PD 157655 & PD 158780 & PD 159119 & PD 159121 & PD 158294 \\
\hline A-431 & 3 & $>50$ & 32 & 40 & $>50$ & $>50$ \\
MDA-468 & 6.7 & $>50$ & 29 & 12 & 30 & $>50$ \\
MDA-231 & 25 & $>50$ & $>50$ & $>50$ & $>50$ & $>50$ \\
SKOV-3 & 2 & 1 & 18 & $>50$ & 6.5 & 20 \\
U-87 & 6 & $>50$ & $>50$ & $>50$ & $>50$ & $>50$ \\
\hline
\end{tabular}

We set out to determine if the anti-proliferative effects of this and the related compounds shown in Figure 1 are the result of blocking the EGFR signal transduction pathway. This was examined by: (1) testing for anti-proliferative effects, (2) testing for receptor specificity and (3) comparing the concentrations needed to block exogenous EGF effects to those needed to block proliferation.

\section{Materials and methods}

\section{Cell lines and culture conditions}

A-431, MDA-MB-468, U-87, SKOV-3 and MDAMB-231 cells were purchased from American Type Culture Collection (Rockville, MD) and maintained at $37^{\circ} \mathrm{C}$ in a $5 \% \mathrm{CO}_{2}$ atmosphere in minimal essential medium (IMEM) (Gibco BRL, Grand Island, NY) supplemented with $10 \%$ fetal bovine serum (FBS) (Gibco BRL, Grand Island, NY). EGFR transfectants and 32D cells were kindly provided by Jacklyn M. Pierce and maintained at $37^{\circ} \mathrm{C}$ in $5 \% \mathrm{CO}_{2}$ atmosphere in RPMI 1640 (Mediatech, Herndon, VA) supplemented with IL-3 (R\&D Systems, Minneapolis, MN) or EGF (UBI, Lake Placid, NY) and 10\% fetal bovine serum (Biofluids Inc., Rockville, MD).

\section{Crystal violet growth assay}

Human tumor cell lines were plated in 96-well plate (Falcon, Lincoln Park, NJ) at 1000-2000 cells per well in IMEM media supplemented with $10 \%$ FBS. The next day, $10 \mathrm{mM}$ stock concentrations of drugs were prepared by dissolving in DMSO then added to cells after diluting in IMEM plus 10\% FBS to the indicated concentrations. Control cells were treated with the corresponding concentrations of DMSO. After 3 days

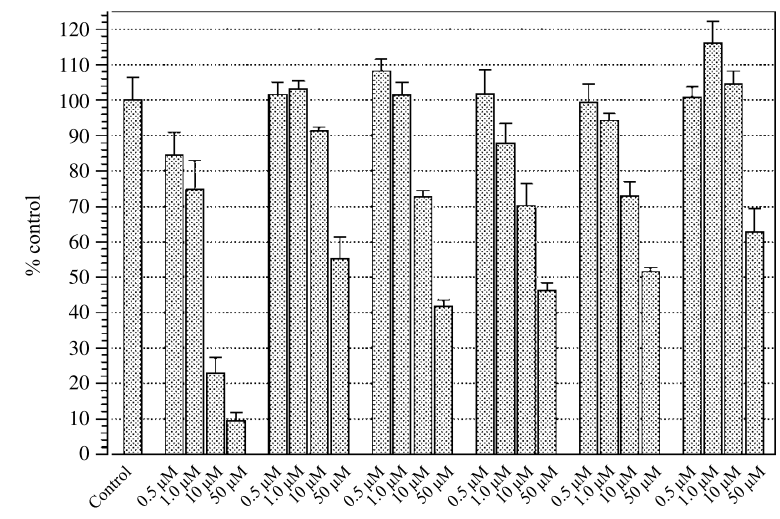

Figure 2. Growth inhibitory effects on A-431 cells. Cells treated with indicated concentrations of compounds. Cell number quantitated using crystal violet staining assay as described in Materials and methods and plotted as percentage control. Results represent mean \pm standard deviation of three replicates per point.

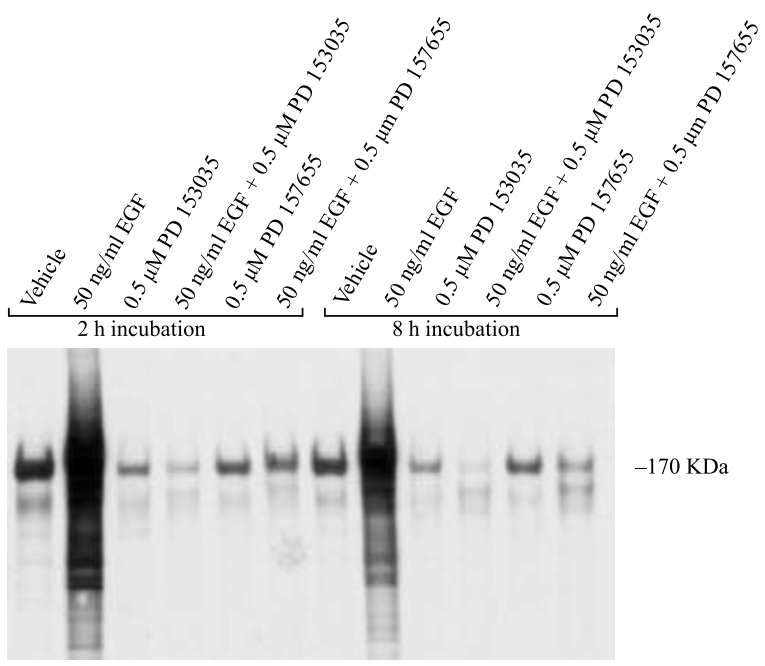

Figure 3. Western blot of A-431 cells treated with PD 153035, PD 157655 and EGF. Whole cell lysates normalized to cell number were probed with anti-phosphotyrosine as described in Materials and methods. 


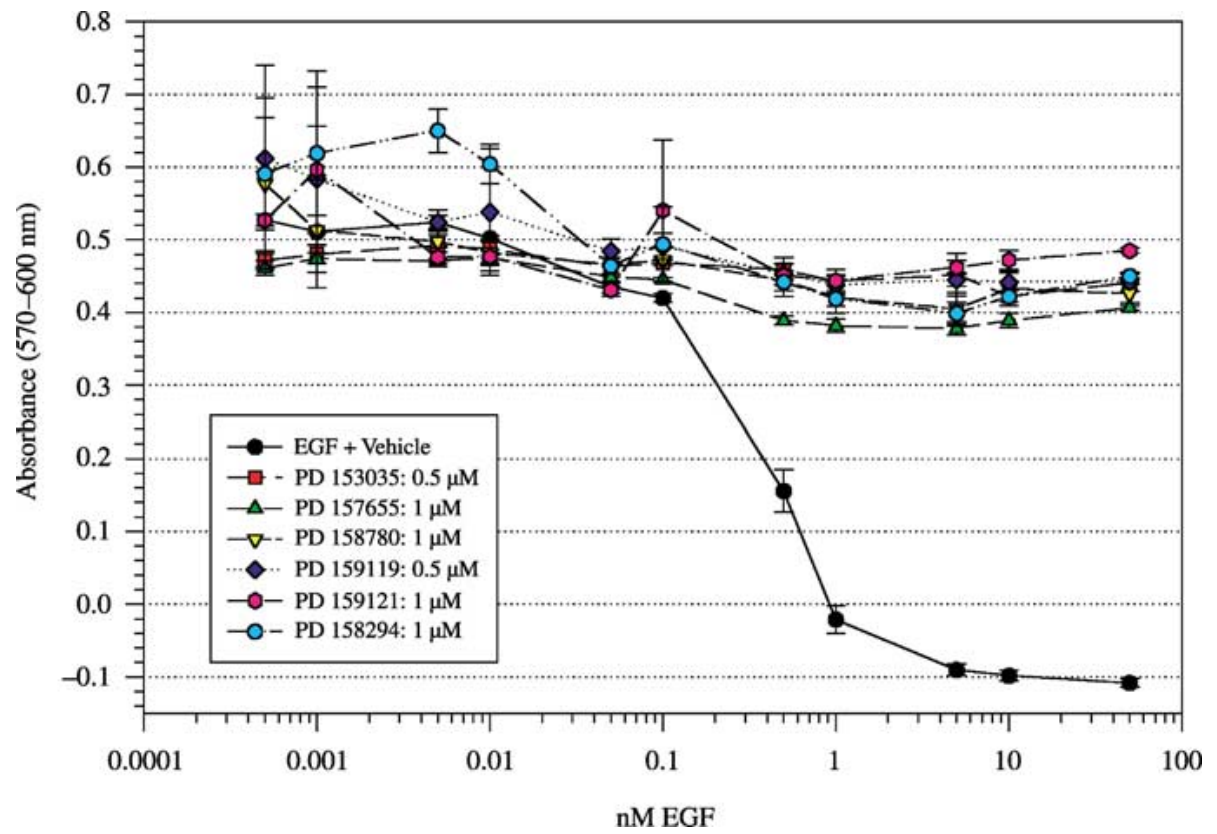

Figure 4. Blocking of EGF toxicity on A-431 cells with indicated concentrations of compounds. Cell number measured with Alamar blue assay as described in Materials and methods and plotted as absorbance $(570-600 \mathrm{~nm})$. Results represent mean \pm standard deviation of three replicates per point.

the cells were gently washed with 1 XPBS, fixed and stained in a $25 \%$ methanol solution with $0.5 \%$ crystal violet for $5 \mathrm{~min}$. Excess stain was removed by gently washing the plates in water. After plates were allowed to dry overnight, the crystal violet was re-solubilized with $0.1 \mathrm{M}$ sodium citrate in $50 \%$ ethanol and absorbance read at $570 \mathrm{~nm}$ against a reference wavelength of $405 \mathrm{~nm}$.

\section{Alamar blue growth assay}

EGFR transfected 32D cells were plated in 96-well plates (Falcon, Lincoln Park, NJ) at 2000 cells per well in the presence if IL-3 or EGF. Immediately after plating cells were treated with indicated concentrations of compounds diluted from stock in RPMI 1640 supplemented $10 \%$ FBS plus IL-3 or EGF. Human tumor cell lines were plated at 1000-2000 cells per well and were allowed to attach overnight. The next day, the cells were treated with compounds diluted in IMEM plus $10 \%$ FBS to the indicated concentrations. In each experiment control cells were treated with the corresponding concentrations of DMSO. Twenty four hours after the start of treatment, Alamar Blue Dye (BioSource International, Camarillo, CA) was added to the wells at a final concentration of $7.5 \%$ and $24 \mathrm{~h}$ later absorbance measured at 570 and $600 \mathrm{~nm}$ and per-

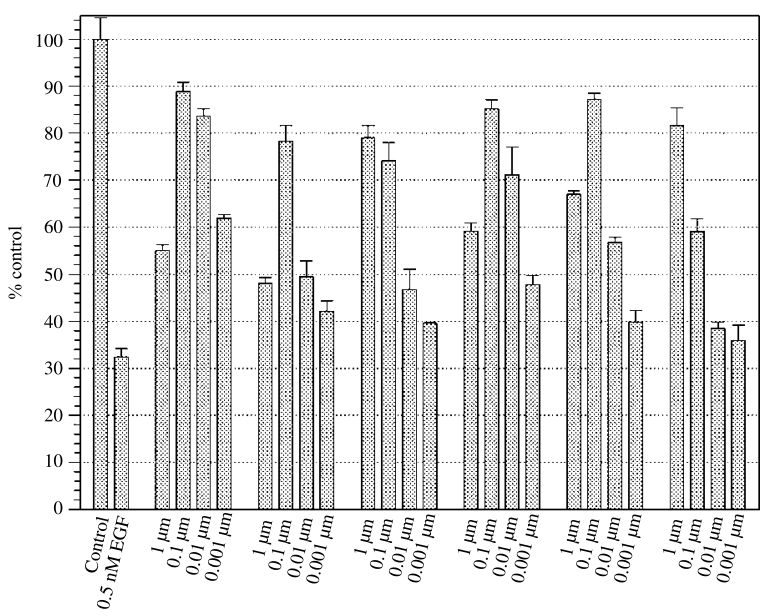

Figure 5. Growth inhibitory effects of EGF on A-431 cells is blocked bi-phasically by tyrosine kinase inhibitors. Cells treated with $0.5 \mathrm{nM}$ EGF were co-treated with indicated concentrations of compounds. Cell number quantitated using crystal violet staining assay as described in Materials and methods then plotted as percentage control. Results represent mean \pm standard deviation of three replicates per point.

centage control was calculated as [(O.D. $570 \mathrm{~nm}-\mathrm{O} . \mathrm{D}$. $600 \mathrm{~nm})$ of treated cells/(O.D. $570 \mathrm{~nm}-$ O.D. $600 \mathrm{~nm})$ of control cells] $\times 100 \%$. 


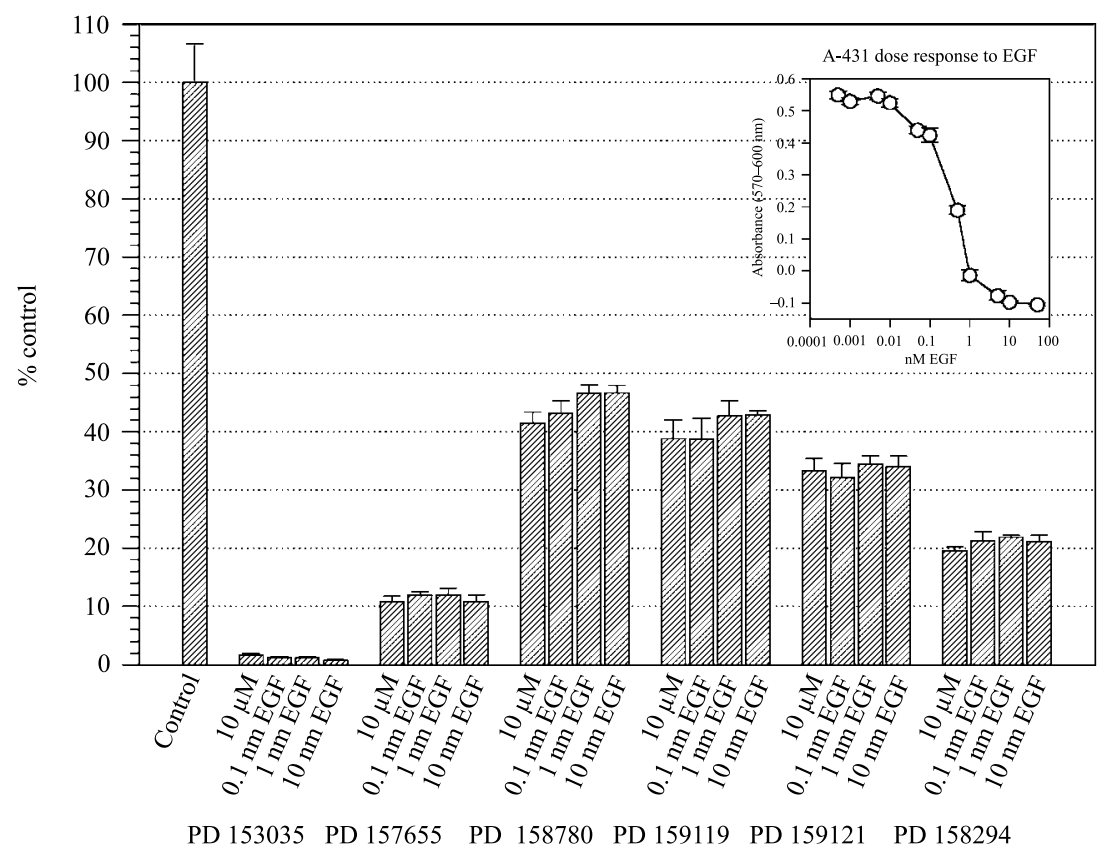

Figure 6. Growth inhibitory effects of compounds cannot be reversed with indicated concentrations of EGF. Cell number measured with crystal violet assay as described in Materials and methods and plotted as percentage control. Results represent mean \pm standard deviation of three replicates per point.

\section{Western blotting}

Human tumor cell lines were plated in 24-well plates (Falcon, Lincoln Park, NJ) at $2 \times 10^{5}$ cells per well in IMEM media supplemented with $10 \%$ FBS. The next day, the media was replaced with IMEM plus $10 \%$ FBS supplemented with $50 \mathrm{ng} / \mathrm{ml}$ EGF alone and in combination with each compound at $0.5 \mu \mathrm{M}$. Control cells were treated with the corresponding concentrations of DMSO. After 2 or $8 \mathrm{~h}$ the cells were washed twice with ice-cold $1 \times$ PBS (Biofluids Inc., Rockville, MD) and lysed $1 \mathrm{ml}$ lysis buffer $(50 \mathrm{mM}$ Tris-HCL, pH 7.4, $150 \mathrm{mM} \mathrm{NaCl}, 5 \mathrm{mM} \mathrm{MgCL}_{2}$, $1 \%$ Triton X-100, $5 \mathrm{mM}$ EDTA, $5 \mathrm{mM}$ EGTA, $1 \mathrm{mM}$ PMSF, $50 \mu \mathrm{g} / \mathrm{ml}$ approtinin, $50 \mathrm{ug} / \mathrm{ml}$ leupeptin and $2 \mathrm{mM}$ sodium orthovanadate). Protein concentration was determined by BCA method (Pierce, Rockford, IL) according to manufacturer's instructions. Thirty micrograms of protein was electrophoresed under denaturing conditions on a Tris-glycine $16 \%$ acrylamide gel (NOVEX Corp., San Diego, CA) and electroblotted onto nitrocellulose membranes. Membranes were blocked overnight in 5\% BSA in 1 XPBS. On the next day membranes were incubated in primary antibody against anti-phosphotyrosine (UBI, Lake Placid, NY) and visualized with ECL (Amersham, Arlington Heights, IL).

\section{Results}

Initially we wanted to test the compounds (chemical structures shown in Figure 1) for their growth inhibitory effects on a variety of human tumor cell lines. Dose response curves were generated for each compound for each cell line and the number of cells determined using the crystal violet growth assay. EC50's were calculated from the each dose response curve and are shown in Table 1. PD 153035 proved the most potent on the cell lines tested with an EC50 of $3 \mu \mathrm{M}$ for the epidermoid cell line A-431. The five related compounds blocked growth to a lesser extent as can be seen in Figure 2. Similar effects were seen on the breast cancer cell line MDA-MB468 with an EC50 value of $6.7 \mu \mathrm{M}$ for PD 153035. Another breast cancer cell line MDA-MB-231 which has a mutated K-Ras and does not respond to EGF [19] had an EC50 of $25 \mu \mathrm{M}$. The ovarian carcinoma cell line SKOV-3 which expresses high levels of the EGFR family member erbB2 [20] but relatively low levels of EGFR was the most sensitive to the compounds with an EC50 for PD 153035 of $2 \mu \mathrm{M}$. Additionally, U-87 cells which have low levels of EGFR [21] have an EC50 similar to that of MDA-MB-468 cells. 

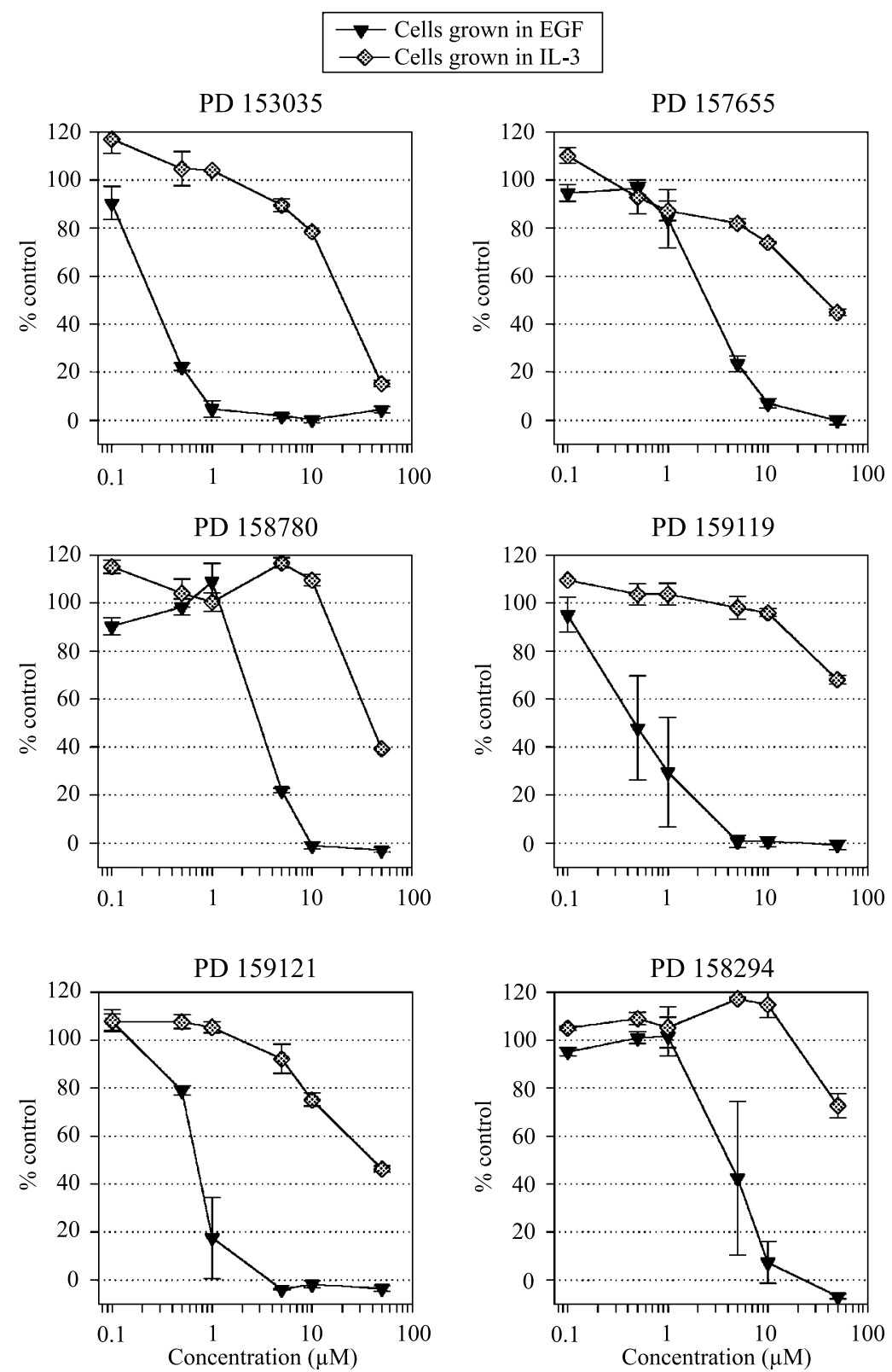

Figure 7. Dose response of EGFR transfected 32D cells grown in IL-3 or EGF. Cell number measured with Alamar blue assay as described in Materials and methods and plotted as percentage control. Results represent mean \pm standard deviation of three replicates per point.

Next we wanted to determine if the growth inhibitory effects seen with the compounds were due to blocking the EGF signaling pathway. We used western blot analysis to determine if the compounds could block the EGF induced tyrosine kinase activity of A431 cells. Cells were incubated with $50 \mathrm{ng} / \mathrm{ml}$ EGF and each compound at $0.5 \mu \mathrm{M}$ for 2 or $8 \mathrm{~h}$. Representative results with PD 153035 and 157655 can be seen in Figure 3. As shown, each compound at $0.5 \mu \mathrm{M}$ was able to completely block the phosphorylation induced by EGF. To further demonstrate specificity we used another system to see if PD 153035 could block the growth inhibitory effects of EGF. A-431 cells express $1-3 \times 10^{6}$ EGFR per cell and respond bi-phasically to EGF [22]. This is a paradoxical effect of EGF seen in vitro whereby low concentrations exhibit a slight stimulation while higher concentrations cause complete growth inhibition with an EC50 value of ap- 
proximately $0.5 \mathrm{nM}$. Using the results from the growth inhibition assays we chose sublethal doses of the compounds to block the effects of EGF in this system. A fixed amount of each compound was incubated with cells grown in increasing concentrations of EGF. As seen in Figure 4 each compound was able to completely block the effects of EGF on A-431 cells at concentrations $\leq 1 \mu \mathrm{M}$. A parallel set of experiments were then conducted on MDA-MB-468 cells which show similar EGFR expression and EGFR responsiveness to A-431 cells [23]. Results similar to A-431 were obtained (data not shown). Next, we determined the least amount of compound needed to block the EGF effects on A-431 cells by incubating cells with an inhibitory concentration of EGF and decreasing amounts of each compound. PD 153035 at $0.01 \mu \mathrm{M}$ was able to block the effects of EGF as shown in Figure 5. We then tried to reverse the growth inhibitory effects of the compounds seen at higher doses $(10 \mu \mathrm{M})$ with the addition of EGF. As seen in Figure 6, EGF was unable to reverse the growth inhibitory effects of any of the compounds.

To further test potency and specificity we screened the compounds for growth inhibition in the 32D cell system. 32D cells are an immortalized murine hematopoietic cell line that is dependent on IL-3 for growth. However, when stably transfected with EGFR, they are able to proliferate in response to EGF in the absence of IL-3 [24]. To quantitate cell number we used the Alamar blue assay because these cells grow in suspension and therefore, the crystal violet staining method was not suitable. The EGFR transfectants were grown in the presence of EGF or IL-3 and increasing concentration of the compounds. The resulting dose response curves can be seen in Figure 7. PD 153035 showed the most dramatic difference in effect with EC50 values of $0.25 \mu \mathrm{M}$ and $20 \mu \mathrm{M}$ for cells grown in EGF and IL-3, respectively. In addition, the compounds were tested for growth inhibition on the parent 32D cell line grown in IL-3 and the resulting dose responses were the same as those for the transfectants in IL-3 (data not shown).

\section{Discussion}

In this study we wished to determine if the growth inhibitory effects of six small molecules on tumor cells were due to blocking of the EGFR signaling pathway. PD 153035 has been shown to block phosphorylation of tyrosine residues on EGFR by blocking the
ATP binding site on the cytoplasmic domain of the receptor with an apparent $K_{i}$ of $5.2 \pm 1.2 \mathrm{pM}$ [18]. We tested the compounds for their growth inhibitory effects on a panel of EGFR expressing cell lines in vitro and for their ability to block EGF induced tyrosine kinase activity and EGF induced killing of tumor cells. We then compared the concentrations needed for each effect.

The compounds were first tested for their ability to inhibit the growth of several tumor cell lines that vary in their responsiveness to EGF. These in vitro experiments generated EC50 values of $3 \mu \mathrm{M}$ or greater for cells which express high levels of EGFR and respond to EGF. Further studies showed that these compounds completely block the effects of exogenously added EGF on these cells at levels less than $0.5 \mu \mathrm{M}$. These results were shown by the ability to block the growth inhibitory effects of EGF on A-431 cells and MDAMB-468 cells and by probing western blots of whole cell extracts of EGF treated A-431 cells with antiphosphotyrosine. PD 153035 was able to block the growth inhibitory effects of EGF on A-431 at a concentration as low as $0.01 \mu \mathrm{M}$. Additional experiments using the novel 32D cell system were able to generate dose response curves for cells grown in EGF and IL-3. These experiments show that sustained repression of EGFR tyrosine kinase activity can be achieved at low concentrations of these compounds while higher levels are required to block proliferation of what is apparently non-EGF dependent growth. All of these studies show that these lipophilic compounds were able to penetrate the cell membrane and reach their proposed site of action. In addition, exogenously added EGF was unable to block the growth inhibition seen at the higher drug concentrations. The culture conditions for the growth experiments were the same as that for the blocking experiments and preparation of cells for western blots to eliminate variations do to serum content.

Our results show that micromolar concentrations were needed to block growth of human tumor cell lines while nanomolar concentrations were able to completely block the effects of exogenously added EGF as determined by the blocking experiments and western blots analysis. In addition, blocking EGF dependent growth in EGFR transfected 32D cells was achieved in the nanomolar range, nearly two logs lower than concentrations needed to block IL-3 dependent growth in the same cells. This difference in response was not seen in the tumor cell lines when we compared the high EGFR expressing/EGF responsive cell lines to 
the low EGFR expressing/EGF non-responsive cells. The EGF responsive A-431 and MDA-MB-468 cells were less than 10-fold more sensitive to these compounds than the EGF non-responsive MDA-MB-231 cells. Furthermore, SKOV-3 cells which have low levels of EGFR and very high levels of the EGFR family member erbB2 were actually the most sensitive. This may reflect the smaller number of EGF receptors which must be targeted in SKOV-3 cells and EGFR transfected 32D cells.

Our experiments have shown that these compounds can block the effects of EGF and can inhibit the growth of tumor cells in vitro, however, concentrations needed for growth inhibition are higher than those needed to block the effects of exogenous EGF indicating a second site of action for these compounds. A possible explanation for these results is the presence of other EGFR family members in these cell lines. EGFR can heterodimerize with at least two of these family members [25]. These compounds do not block EGF binding to its receptor, which is a prerequisite for dimerization, therefore the mitogenic signal may be propagated when EGFR heterodimerize with other family members. In addition, PD 153035 was shown to inhibit the tyrosine kinase activity of erbB-2 with an IC50 of $2.3 \mu \mathrm{M}$ [16] and its activity on the other EGFR family members has not been looked at. These compounds are growth inhibitory at levels greater than $1 \mu \mathrm{M}$ which may be the levels needed to block the other EGFR family members. This may also explain the effects seen on SKOV-3 cells. Clearly inhibition of other unrecognized ligand mediated or intracellular tyrosine kinases is possible. This hypothesis is consistent with results from Davies et al. [26] who showed that the many protein kinases exhibited activity on genes other than the desired target.

Bos et al. have shown that PD 153035 inhibits the growth of several tumor cell lines in vitro and this correlates with the level of EGF receptor expression [27]. In our studies we do not see this correlation. This may be caused by the differences in growth conditions. Our growth assays were conducted in media containing $10 \%$ FBS where as Bos et al. tested in reduced FBS $(0.5 \%)$. Our growth conditions may make the cells less dependent on autocrine signaling and therefore growth inhibition is seen only at concentrations that are nonspecific.

We have shown that PD 153035 is the most efficacious of the compounds tested. In addition, we have shown that these compounds can block the effects of exogenous EGF at nanomolar concentrations and can inhibit growth only at much higher concentrations. Therefore, we conclude that the growth inhibitory effects are mediated by a second site of action for these compounds.

\section{Acknowledgements}

We are grateful to Dr David Fry for kindly providing us with the tyrosine kinase inhibitors and to Dr Jackie Pierce (NCI) for providing the 32D cells. This work was supported by a Specialized Project of Research Excellence Grant (Breast) from the National Cancer Institute (1P50CA58185).

\section{References}

1. Carpenter G, Cohen S: Epidermal growth factor. J Biol Chem 265: 7709-7712, 1990

2. Tokunaga A, Onda M, Okuda T, Teramoto T, Fujita I, Mizutani T, Kiyama T, Yoshiyuki T, Nishi K, Matsukura N: Clinical significance of epidermal growth factor (EGF), EGF receptor, and c-erbB-2 in human gastric cancer. Cancer 75: 1418-1425, 1995

3. Shimada Y, Imamura M: Prognostic factors for esophageal cancer - from the viewpoint of molecular biology. Gan To Kagaku Ryoho 23: 972-981, 1996

4. Klijn JG, Berns PM, Schmitz PI, Foekens JA: The clinical significance of epidermal growth factor receptor (EGF-R) in human breast cancer: a review on 5232 patients. Endocr Rev 13: 3-17, 1992

5. Ware JL: Growth factors and their receptors as determinants in the proliferation and metastasis of human prostate cancer. Cancer Metastasis Rev 12: 287-301, 1993

6. Sobol RE, Astarita RW, Hofeditz C, Masui H, Fairshter R, Royston I, Mendelsohn J: Epidermal growth factor receptor expression in human lung carcinomas defined by a monoclonal antibody. J Natl Cancer Inst 79: 403-407, 1987

7. Derynck R, Goeddel DV, Ullrich A, Gutterman JU, Williams $\mathrm{RD}$, Bringman TS, Berger WH: Synthesis of messenger RNAs for transforming growth factors alpha and beta and the epidermal growth factor receptor by human tumors. Cancer Res 47: 707-712, 1987

8. Osborne CK, Coronado-Heinsohn E: Targeting the epidermal growth factor receptor in breast cancer cell lines with a recombinant ligand fusion toxin (DAB389EGF). Cancer J Sci Am 2: 175,1996

9. Suwa T, Ueda M, Jinno H, Ozawa S, Kitagawa Y, Ando N, Kitajima M: Epidermal growth factor receptor-dependent cytotoxic effect of anti-EGFR antibody-ribonuclease conjugate on human cancer cells. Anticancer Res 19: 4161-4165, 1999

10. Kihara A, Pastan I: Cytotoxic activity of chimeric toxins containing the epidermal growth factor-like domain of heregulins fused to PE38KDEL, a truncated recombinant form of Pseudomonas exotoxin. Cancer Res 55: 71-77, 1995

11. Mendelsohn J: Epidermal growth factor receptor inhibition by a monoclonal antibody as anticancer therapy. Clin Cancer Res 3: 2703-2707, 1997 
12. Mendelsohn J: Jeremiah Metzger Lecture. Targeted cancer therapy. Trans Am Clin Climatol Assoc 111: 95-110, 2000

13. Baselga $\mathrm{J}$ : New therapeutic agents targeting the epidermal growth factor receptor. J Clin Oncol 18: 54S-59S, 2000

14. Ciardiello F: Epidermal growth factor receptor tyrosine kinase inhibitors as anticancer agents. Drugs 60(1): 25-32, 2000

15. Raymond E, Faivre S, Armand JP: Epidermal growth factor receptor tyrosine kinase as a target for anticancer therapy. Drugs 60(1): 15-23, 2000

16. Khazaie K, Schirrmacher V, Lichtner RB: EGF receptor in neoplasia and metastasis. Cancer Metastasis Rev 12: 255-274, 1993

17. Moscatello DK, Holgado-Madruga M, Godwin AK, Ramirez G, Gunn G, Zoltick PW, Biegel JA, Hayes RL, Wong AJ: Frequent expression of a mutant epidermal growth factor receptor in multiple human tumors. Cancer Res 55: 5536-5539, 1995

18. Fry DW, Kraker AJ, McMichael A, Ambroso LA, Nelson JM, Leopold WR, Connors RW, Bridges AJ: A specific inhibitor of the epidermal growth factor receptor tyrosine kinase. Science 265: 1093-1095, 1994

19. Ennis BW, Valverius EM, Bates SE, Lippman ME, Bellot F, Kris R, Schlessinger J, Masui H, Goldenberg A, Mendelsohn $\mathrm{J}$ : Anti-epidermal growth factor receptor antibodies inhibit the autocrine-stimulated growth of MDA-468 human breast cancer cells. Mol Endocrinol 3: 1830-1838, 1989

20. Shawver LK, Mann E, Elliger SS, Dugger TC, Arteaga CL: Ligand-like effects induced by anti-c-erbB-2 antibodies do not correlate with and are not required for growth inhibition of human carcinoma cells. Cancer Res 54: 1367-1373, 1994

21. Phillips PC, Levow C, Catterall M, Colvin OM, Pastan I, Brem $\mathrm{H}$ : Transforming growth factor-alpha-Pseudomonas exotoxin fusion protein (TGF-alpha-PE38) treatment of subcutaneous and intracranial human glioma and medulloblastoma xenografts in athymic mice. Cancer Res 54: 1008-1015, 1994
22. Kawamoto T, Sato JD, Le A, Polikoff J, Sato GH, Mendelsohn J: Growth stimulation of A431 cells by epidermal growth factor: identification of high-affinity receptors for epidermal growth factor by an anti-receptor monoclonal antibody. Proc Natl Acad Sci USA 80: 1337-1341, 1983

23. Filmus J, Pollak MN, Cailleau R, Buick RN: MDA-468, a human breast cancer cell line with a high number of epidermal growth factor (EGF) receptors, has an amplified EGF receptor gene and is growth inhibited by EGF. Biochem Biophys Res Commun 128: 898-905, 1985

24. Di Fiore PP, Segatto O, Taylor WG, Aaronson SA, Pierce JH: EGF receptor and erbB-2 tyrosine kinase domains confer cell specificity for mitogenic signaling. Science 248: 79-83, 1990

25. Earp HS, Dawson TL, Li X, Yu H: Heterodimerization and functional interaction between EGF receptor family members: a new signaling paradigm with implications for breast cancer research. Breast Cancer Res Treat 35: 115-132, 1995

26. Davies SP, Reddy H, Caivano M, Cohen P: Specificity and mechanism of action of some commonly used protein kinase inhibitors. Biochem J 351: 95-105, 2000

27. Bos M, Mendelsohn J, Kim YM, Albanell J, Fry DW, Baselga $\mathrm{J}$ : PD153035, a tyrosine kinase inhibitor, prevents epidermal growth factor receptor activation and inhibits growth of cancer cells in a receptor number-dependent manner. Clin Cancer Res 3: 2099-2106, 1997

Address for offprints and correspondence: JM Rae, $\mathrm{PhD}, \mathrm{Di}-$ vision of Hematology and Oncology, Department of Internal Medicine, University of Michigan Medical Center, 5323 Med. Sci 1, 1150 W. Medical Center Drive, Ann Arbor, MI 481090612, USA; Tel.: +1-734-764-1460; Fax: +1-734-615-7019; E-mail: jimmyrae@umich.edu 